organization, is dependent on the goodwill of those concerned in its operation, and Dr. Martin regretted that no provision was made for the direct representation of the Association of Applied Biologists or of the advisory services on the organization.

In Dr. Martin's opinion, personal contact is the royal road to the full application of biology to agriculture, but for the grower the printed or written word is the best form of memorandum. After citing instances of the failure of the results of research to be transmitted in proper perspective to the grower, Dr. Martin commended to the Agricultural Improvement Council the appointment of a corps of intelligence or public relations officers. Such officers should be journalists acquainted with both practical and scientific aspects, able to translate research into vivid workaday English, wise enough to avoid sensationalism and to seek expert advice on their scripts before publication. To foster mutual confidence they should move freely among growers, advisory officers and research workers.

\section{Responsibilities of Scientific Societies}

THe latter part of Dr. Martin's address is devoted to the wider questions of the post-war responsibilities of the Association of Applied Biologists, particularly in presenting a common front with other scientific men to guide the application of science. Science, he said, must protect itself from exploitation and must also accept responsibility not only in safeguarding humanity against such misuse, but also in ensuring that mankind shall profit to the full by the impact of science. In furtherance of this, Dr. Martin suggested subdivision of the Society not on a geographical but on a subject basis, each subject group dealing with the applied aspects of one particular branch of biology. The subject groups would then serve to link together all biological sciences in an organization capable of exerting a unified pressure, yet bound not by rigid rule or order but by common interests and responsibilities. $\mathrm{He}$ believes such a method would provide for collaboration with the academic societies without necessitating the segregation of nonpathological members of the Association in accordance with W. C. Moore's suggestion to the British Mycological Society. Moreover, it could also be made to serve the unification of science by counterbalancing the economic tendency of the larger publishing societies to lose contact.

Discussing further the formation of a united scientific front, Dr. Martin believes that this is more likely to be achieved with the publishing societies rather than the professional societies as the basis for its organization. He visualizes a Science Council on which the sciences would be represented by election from the publishing societies. Such a Council should, he urged, set up a main committee with sub-committees in the different sciences, which, with philological representation, would extend the work on nomenclature to that of terminology at its broadest. Its task would be to guide the evolution of language and to add to its precision as an instrument of science. $\mathrm{He}$ pleaded also for a simplification of spelling, but even more important than a common language is the task of training humanity in those principles to which science itself is dedicated. The primary task of the Commonwealth of Science is to convert mankind to the methods and ethics of science; to train the young in the discipline of science; to instil into statesmen and politicians the spirit of science and to show commerce that there is more profit in the full application of science than its exploitation. This would involve a fundamental change in the status of the sciences in education and a change in the attitude of the scientific hierarchy towards the political responsibilities of science. He thinks that the danger of fundamental science becoming neglected is illusory, but he deplored any industrial pressure which restrains publication of knowledge. Patent laws encouraging such restriction should be repealed. The danger of falling from scientific grace is no reason for monastic seclusion and for refusal to participate in building up a science front strong enough to withstand any form of pressure, or to correct political and industrial offences against scientific interests and principles.

\section{The Lister Institute of Preventive Medicine}

THE report for 1943 of the Lister Institute of Preventive Medicine marks the fiftieth anniversary of the beginning of its scientific work and records work of a quality which reflects great credit on Sir John Ledingham, who has recently retired from the directorship, and on all his staff. The war-time dispersal of some of the staff to other laboratories may have its disadvantages, but it must have brought advantages also through the closer contacts made with other workers. For thirty-eight years Sir John Ledingham has been a member of the staff of the "Lister", and thirteen years ago he succeeded Sir Charles Martin as director. These are two names respected by every man of science; they both call up the vision of indefatigable work devoted to the betterment of the lot of mankind, the vision of men who have never sought publicity, of strong personalities whose modesty has always been an inspiration to all who came into contact with them. It is good to know that both are still at work. Every scientific worker will wish to take this opportunity to add to their public honours his tribute to their generous comradeship with the younger generation, their continual output of ideas, assistance and more and yet more results of their own outstanding labours.

\section{Diet of Wood Pigeons}

THE recently issued sixth bulletin on wood pigeon studies being organized from the British Trust for Ornithology at Oxford contains some interesting observations of agricultural importance. The examination of nearly 4,000 wood pigeon crops suggests that, contrary to the general belief of farmers, wood pigeons do not eat the 'heart' or buds of clover plants ; they eat the leaves and not the buds. Nor do they normally eat young corn but only the seed. During the mild winter of January and February 1943, wild fruits like ivy bexries, haws and acorns were found in the 393 crops examined, whereas during the more normal winter of January and February 1942 (13I crops examined) the main food was shown to be cultivated clover. With the co-operation of phenologists a record is being made of the local variations in the abundance of acorn crops, because this seems to be the controlling factor for the movements of the wood pigeon flocks in Great Britain in winter. This might influence forestry work. The food habits of the smaller stock dove are shown to differ. This bird does not take the same food as the wood pigeon : it appears to be more of a ground-feeding species, living almost entirely upon cereals, weed seeds and roots. When the extra acres of woodland are scientifically managed after the War, they may attract the wood pigeon to feed there in the autumn instead of in the farm fields. 